\title{
A Portrait of Hugo Claus as a Young Artist: the influence of James Joyce on The Sorrow of Belgium
}

Many great works of literature are haunted by apocryphal stories about their beginnings. It is said that James Joyce (1882-1941) burned a portion of Stephen Hero, the first draft of the semi-autobiographial Künstlerroman that was to become $A$ Portrait of the Artist as a Young Man (1916), 'in a fit of momentary despair and then started the novel anew in a more compressed form'. The tale has passed into folklore even though the surviving pages of the manuscript are not in the least bit singed. Years later, Hugo Claus (1929-2008) publicly declared that he tossed the first version of his great semi-autobiographical, coming of age novel Het Verdriet van België [The Sorrow of Belgium] (1983) into the fire in front of friends, ceremonially laying waste to four years' work, having realised that 'it was too heavily oriented towards my personal psyche' [dat het te zeer op mijn persoonlijke psyche gericht was]. He confessed to having 'squirreled away the best fragments beforehand in order to use them again later, like the grocer that every writer is' [nadat ik, als de kruidenier die elke schrijver is, vooraf de beste fragmenten had weggeborgen om ze later nog eens te gebruiken]. Of course, these fits of pique can be dismissed as expressions of the fiery temperament that cliché attributes to the thwarted artist. However, it is possible that by this act Claus was signalling a certain kinship with Joyce as a writer, not least because Claus's striking metaphor for textual reclamation chimes with Joyce's famous artistic boast: 'I have a grocer's assistant's mind'.

This article is the first in English or Dutch to examine in fine detail striking and extensive similarities in subject matter and technique that link Het Verdriet van België to A Portrait of the Artist as a Young Man and, to a lesser extent, Ulysses. It proposes that, although references to Joyce are nowhere explicitly foregrounded in Claus's novel, he in fact absorbed Joyce's work so thoroughly that his example disappears behind the text while nonetheless remaining a pervasive presence. If the influence of Portrait and Ulysses on Het Verdriet appears omnipresent, it is because Claus has universalised the struggles of the aspiring artist who would extricate himself from the blinkered philosophies of those around him in order to initiate a new artistic conscience, and therefore the experimental narrative techniques and compositional practices that arise from such a quest. If Claus has effaced his debt to Joyce, it is because his ego would not bear extensive comparison at a time when he was seeking 
to define an emerging national consciousness, a task that demands a unique and unprecedented insight.

Harold Bloom was the first critic to articulate the anxiety that strong precursors inspire in later writers. Although his grandiose study The Anxiety of Influence (1973) is focused on the British Romantic poets, and takes no account of individual biography, Bloom's thesis that an artist who aspires to the independent originality that is the mark of enduring genius must sublimate influence through 'creative misprision' to spare his fragile self-confidence as an autonomous creator is applicable here, and provides a broad context from which to consider Claus's progressive effacement of Joyce from his works. Beyond matters of authorial psychology and the originality of imitation, adaptation, and allusion, the act of placing influence under erasure requires further consideration of the ambiguous relations between texts that are at once proximate yet not explicitly linked, the degree to which similarities are conscious, and the hinterland between direct allusion with a recoverable referrent and the diffuse intertextuality that Roland Barthes and others identify to be the fundamental condition of all language and literary works.

The first factor to consider is the oddly parallel course of the young lives of Joyce and Claus, and therefore Louis and Stephen, which bear significant comparisons despite their having grown up in different countries half a century apart. A Portrait of the Artist as a Young Man documents the spiritual growth of Joyce's fictionalised alter-ego Stephen Dedalus, who is born to Irish Catholic nationalists in the 1880s. It follows the convoluted passage towards freedom that Stephen takes as he navigates his school and university days and attempts to transcend the complex religious, political and social formations that hold Ireland back in order to become the artist of a new national consciousness. It is in many respects the paradigmatic example of the Künstlerroman, because it fictionalises the early career of the artist who would ultimately write Ulysses, the epic novel that Claus and countless other writers and critics hold up as the most important and influential literary work of the twentieth century. Het Verdriet presents the artistic maturation of Louis Seynaeve, a morally flawed but gifted adolescent who is likewise a fictionalised version of Claus's younger self. Louis chafes against his Catholic education, joins the National Socialist 
Youth Movement of Flanders [Nationaal-Socialistische Jeugd Vlaanderen], but gradually distances himself from the politics and narrowmindedness of his family (who are ardent Flemish nationalists and collaborate with the Nazis during the Second World War) to fulfil his aspiration to reimagine his nation's history at its most perilous time. This task can only be accomplished once Louis has seen through and transcended the blinkered conservatism, religiosity and nationalism that would make many Flemings receptive to the poisonous Nazi ideology, which would be a source of deep sorrow for Flanders for decades to come.

The similarities between Portrait and Het Verdriet are perhaps not surprising. If a Künstlerroman is to document the maturation of an artist who is to be of any future national importance, it must reveal how he or she comes to disengage from the double standards of the dominant culture, a basic qualification for developing the sensibility that is capable of producing truly radical art. The genre is by nature semiautobiographical, as it inevitably refracts the processes by which the author came into his or her mature self by sloughing off a younger alter-ego. The analogous but distinct historical situations of Catholic Flanders and Ireland serve to strengthen these correspondences. Claus came of age during the occupation of Belgium, a circumstance that intensified pre-existing linguistic, religious and political divisions in Flanders dating from 1830, the year Belgium gained independence, when successive governments pursued a policy of gallicisation that threatened Dutch language and Flemish culture by making French the only language of government and administration. Broadly speaking, these conditions were not dissimilar to those experienced by Joyce growing up in Dublin under British rule, in a country where the native Gaelic had virtually been eradicated in favour of English and pushed out to the western fringes of the country. In both scenarios, systematic oppression kindled grassroots nationalism. In Belgium, the most extreme Flemish nationalists aligned themselves with the Nazis, while in Ireland, the Fenian movement continued a campaign of revolutionary acts against the British until home rule was finally granted in 1922. Schooled in strict Catholic institutions, living in occupied territories, it is not unexpected that the young Claus and Joyce should have had so much in common or that their literary alter-egos should become preoccupied with the workings of religion, language and national identity in their quest to transcend the status quo and equip their future selves to write their country's epic. 
The close and sometimes uncanny resemblance between aspects of Het Verdriet and Portrait in particular sensitises readers with detailed knowledge of Joyce's life and works to further potential points of convergence and divergence, from the broad brush strokes of plot and theme, to the minutiae of compositional strategies. These elements appear so numerous and extensive that the relations no longer seem to be purely coincidental, not least in the context of Claus's extensive critical pronouncements on Joyce's work in relation to his own. The cumulative effect is to incline readers to suspect that the similarity is indeed due to influence rather than mere generic resemblance or the ideological patterns typical of the modernist artistic revolt against 'traditional' stories (of Catholicism and national ideology) and their replacement by other (artistic) mythologies. While the proliferation of correspondences invites a comparative reading that 'literarificates' Het Verdriet by reference to Joyce, there is also the question of how the relations are mediated and how Claus managed the anxieties that attend influence. The following sections seek to shine a light on the potentially Joycean aspects of Claus's novel and its long genesis, starting with Claus's own critical pronouncements on Joyce in essays and interviews and in relation to his writing processes, and then proceeding to comparative accounts of their play with literary form, myth, their attitudes to language, history and Catholicism, their naturalism and avowed anti-clericalism, their capacity for combining stylistic inventiveness with a meticulous realist base, their shared concern with nationalist historiography and the unreliability of perspective, and their highly systematised narrative structures.

The idea that Claus writes in Joyce's wake is not new. When the novel first came out in 1983, Carel Peeters compared Claus's achievement to that of J.D. Salinger and James Joyce. Richard Burns too declared 'The Sorrow of Belgium is impressive in size and ambition: Bildungsroman and epic, it is as if $A$ Portrait of the Artist as a Young Man were written to the scale of Ulysses' in his review of Arnold J. Pomerans's English translation. Four years after Claus's death, the author and actor Guido Lauwaert corroborated the reviewers' assessments by revealing the author's original plans for Het Verdriet in a commemorative set of two articles for the Belgian magazine Knack (2012): 
But Hugo would not be Claus if, in the conceptual period that preceded the writing, he had not sought out a colleague who takes inspiration from his own past, just like him, and stays close to home with his topics. But since he absolutely wanted to write a novel that would be successful as never before, it could not be just any old author. He did not need to look very far, as the shining example lay in the first cellar of the Babelian library of his piratical memory: James Joyce. Which of the Irish writer's books served as the model for the novel that Hugo Claus had in mind is not difficult to guess: the wonderful $A$ Portrait of the Artist as a Young Man [...]

Maar Hugo zou Claus niet zijn, had hij in de conceptuele periode die aan het schrijven voorafgaat, niet naar een collega gezocht die net als hij uit zijn eigen verleden put en met het gegeven dicht bij huis blijt. Maar omdat hij absoluut een roman wilde schrijven waar hij mee zou scoren als nooit voordien, kon het niet zomaar eender welke auteur zijn. Lang moest hij echter niet zoeken, want het grote voorbeeld lag in de eerste kelder van de bibelebontse bibliotheek van zijn piratengeheugen: James Joyce. Welk boek van de lerse schrijver model stond voor de roman die Hugo Claus voor ogen stond valt niet moeilijk te raden, het prachtboek $A$ portret [sic] of the Artist as a Young Man $[\ldots]$

According to Lauwaert, Claus had further intended to write a sequel to Het Verdriet, documenting Louis's transition to adult life, starting with his studies at the Academy of Arts in Ghent, then moving on to the time he spent in Paris. The novel, which never materialised, was to be set in the early 1950s, refracting Claus's formative years as a young artist who gained sexual experience and self-knowledge by living abroad, returning home impoverished but wiser. 'The sequel', Lauwaert explained, 'was supposed to be nothing more or less than a Flemish Ulysses' [wat het vervolg moest worden was niet meer of minder dan een Vlaamse Ulysses]. Lauwaert's account indicates that Claus consciously selected Joyce as his template, not only as a fellow writer who creates from the raw materials of his own life, but also for his monumental standing as a talent equal to his own ambition.

Joyce evidently came to Claus's attention early on in his career. He positioned Ulysses at the pinnacle of the twentieth-century canon in his state-of-the-discipline essay 'The New Novel has Arrived' (1957), where he praised Joyce's talent for conveying the fascination of reconnoitred everyday life and the necessity of grounding literary invention in verifiable realist detail: 
I mean the poetry of people's quotidian actions, observed from afar, of elementary reality. As the best example I cite the fact that James Joyce, while he was wading through the 'Nausicaa' period of his magnus opus Ulysses, wrote to his Aunt Josephine in Dublin to help, namely by describing certain details in the Star of the Sea Church at Sandymount, which he hadn't seen in twenty years. This touch of clear sobriety in the middle of the construction of such an intricate work as Ulysses may tell us a lot about this difficult subject that is the modern novel.

Ik bedoel de poëzie van de dagelijkse, beloerde acties van de mens, de elementaire realiteit. Als best voorbeeld citeer ik het feit dat James Joyce, terwijl hij volop in de Nausicaa-periode van zijn groot werkstuk Ulysses aan het ploeteren was, naar zijn tante Josephine in Dublin schreef om hem erbij te helpen, namelijk door hem bepaalde details in de Star-of-the-Sea-kerk te Sandymount, die hij in geen twintig jaar gezien had, te beschrijven. Deze toets van heldere zakelijkheid midden in de opbouw van een ingewikkeld geschrift als Ulysses moge heel wat verklaren van dit moeilijke ding: de moderne roman.

Claus's comments here indicate that he had already acquired a strong knowledge and understanding of Joyce's writing and compositional techniques, as these observations draw on correspondence that was published that year and was also cited in annotations to primary editions, critical studies and guides.

In subsequent years, Claus often invoked Ulysses as the definitive modern novel in relation to his own writing practices, particularly in relation to the composition of Het Verdriet. In 1973, Claus proclaimed that his decision to leave Belgium for France, Italy and Holland was 'Out of love for my country. You can observe it better by keeping your distance.' [Uit liefde voor mijn land. Je kunt het beter bekijken als je er afstand van neemt.] He added, 'Furthermore, l'll start a big Belgian family novel soon. [...] You need distance for that. James Joyce also wrote about Dublin while living in Trieste', linking the work that was to become Het Verdriet to Joyce's exilic fiction. [Bovendien begin ik binnenkort aan een grote Belgische familieroman. [...] Daar heb je afstand voor nodig. James Joyce schreef ook over Dublin toen hij in Triëst woonde.] Three years later-two years into the writing of Het Verdriet-Claus justified the slow pace of his progress with reference to the compositional history of Ulysses, exclaiming 'why should I rush the novel I'm working on when James Joyce took 8 years to finish his Ulysses?' [Maar wat zou ik mij haasten met de roman waaraan ik bezig ben als 
James Joyce acht jaar over zijn Ulysses heeft gedaan?'] On the subject of Portrait, the novel with which Het Verdriet has most in common, he was conspicuously silent.

The workings of Claus's 'piratical memory' have long been a focus for Claus scholarship. Claus was a talented linguist and prolific literary translator of diverse works in Ancient Greek and Latin, French, German, Italian, Spanish and English. For instance, he 'rewrote' poetry by Shakespeare and Dante (Sonnetten, 1988) and even classical Sanskrit verse ('Nu nog' in Alibi, 1985). In De mot zit in de mythe: Hugo Claus en de oudheid [The Moth is in the Myth: Hugo Claus and Antiquity] (1984), Paul Claes prepared an inventory of classical references in Claus's work in order to assess their form and function, focusing particularly on his psychoanalytic reworkings of the Oedipus myth and his use of the ancient vegetation myths that are fundamental to all human cultures, as set out in James Frazer's classic anthropological study The Golden Bough (1890). Claes compares Claus's free hand with translation, allusion, quotation and myth with that of the modernist poets he most admired, Ezra Pound and T.S. Eliot, who were also steeped in Frazer and likewise confronted the anxiety of influence by reworking old material destructively, leaving it moth-eaten, having digested and then reworked it ironically to structure and clarify their own vision. In Claus-reading (1984), Claes reads Claus closely, but from the structuralist premise that texts are 'een weefsel van allerlei andere teksten, die hij herhaalt of wijzigt, die hij beaamt of afwijst' ['a tissue of all sorts of other texts, which he repeats or changes, which he affirms or rejects'], performing open-readings that emphasise the way existing texts are used and processed (as opposed to closing the play of meaning down).

While Claes's work reveals that the practice of using ancient myth to structure stories and characters' psychologies is germane to Claus's oeuvre, less attention has been given to his kleptographic play with modern sources. In this respect it is fitting that Claus should have alighted on Joyce as the model for the scale of his ambitions for Het Verdriet, for no other modern writer has manipulated myth more archly or comprehensively. Not only did Joyce endow Portrait with (mock) classical gravitas by structuring the narrative in relation to Ovid's account of Dedalus and Icarus, but he performed the most audacious parodic rewriting of the Odyssey by the light of his own times in Ulysses, whereby 'Each adventure (that is, every hour, every organ, every art being interconnected and interrelated in the structural scheme of the whole) should not only condition but even create its own technique'. The proposal that Claus may 
have elevated Joyce's works to the status of the myths by which aspiring writers now comprehend their crafts makes sense in the wider context of his intertextual proclivities.

Claus was capable of reading Portrait and Ulysses (and their mythic counterparts) in the original. He could also have availed himself of Dutch translations of both Joyce's novels, including translations that appeared with his own publisher, De Bezige Bij, in 1972 and 1969 respectively. Of course, Ulysses is a formidable challenge even for native English readers, and it was clearly a daunting prospect for Claus, as he confessed in 1993:

Ulysses is one of the few masterpieces that this terrible planet has produced this century. I tried to read it several times, but I didn't succeed. Sometimes I randomly read twenty or so pages in it. It's the kind of book that should be on your bedside table.

Ulysses is een van de weinige meesterwerken die deze verschrikkelijke planeet deze eeuw heeft voortgebracht. Ik heb het verschillende keren proberen te lezen, maar ben er niet in geslaagd. Soms lees ik willekeurig een pagina of twintig. Het is het soort boek dat op je nachttafeltje moet liggen.

Taking this claim at face value, it is clear that Ulysses remained a constant source of fascination and inspiration for Claus, even if he might have never had succeeded in reading it fully from cover to cover. Whatever the limitations of his reading of Ulysses, by the time Claus embarked on Het Verdriet, he certainly had sufficient grasp of Joyce's oeuvre, and the critical field, to feel confident in declaring the Joycean scale of his ambition, at least in the early stages of the novel's genesis.

It follows that, if Claus was to fulfil his ambition to write the Flemish Ulysses, he might well utilise Joyce's techniques. For instance, the 'clear sobriety' Claus admired in Joyce's fidelity to 'elementary reality' is replicated in Het Verdriet, as illustrated by Claus's explanation why Louis has the surname Seynaeve:

Very simple. If a story is set in the queen of the coastal towns, I consult the phone book of Ostend. For Walle [the fictional town in Het Verdrief] I took the section listing the numbers of Kortrijk [the town in West Flanders where Claus 
was born]. [Heel eenvoudig. Speelt een verhaal zich af in de koningin der badsteden ga ik te rade in het telefoonboek van Oostende. Voor Walle nam ik het deel waar Kortrijk in opgenomen is.]

Joyce made similar use of civic records to authentical his fictional world, most famously drawing on listings from Thom's Official Dublin Directory (1904) so that he could make reference to real businesses and people. However, the potential range of Claus's freewheeling use of Joycean techniques and formal conceits is far more comprehensive and extensive than merely the consultation of reference works, which is the mark of any author of historical fiction worth his or her salt. Indeed, the plot of Het Verdriet appears to exploit the stylistic progression, formal conceits, deep mythical structure and themes of Portrait, combining these with some of the experimental innovations of Ulysses.

Portrait takes the form of a third-person narrative that is vividly focalised through the consciousness of the growing Stephen, flexibly drawing on his distinctive idiolect and thought processes, the style maturing in line with his intellectual development as he moves from home to primary and secondary school, and then university. It concludes with an abrupt transition into the first-person form of Stephen's diary, signalling a degree of artistic autonomy, although the entries are for the most part terse, telegraphic and concerned with the minuitiae of everyday life. In the penultimate entry, Stephen declares his will 'to forge in the smithy of my soul the uncreated conscience of my race'. Stephen's final invocation, 'Old father, old artificer, stand me now and ever in good stead' (212), introduces a note of doubt concerning his current fitness to undertake that task, since he positions himself as son to his mythical namesake Dedalus, the cunning artificer whom, as the epigraph from Ovid informs readers, 'to unimagined arts set his mind'. The quotation refers to the feathered wings fashioned to escape the labyrinth he devised for King Minos and to fly away from the tyranny of the state, only for his overweening son to drown having flown too close to the sun. The novel concludes with two separate lines 'Dublin 1904 / Trieste 1914' that foreground the ambiguities of Stephen's future promise as the young self whom Joyce had to slough off before he could write Ulysses. In making explicit the parallel between Stephen's anticipated but previously deferred departure from Dublin for the continent and Joyce's move to Trieste, readers are invited to step outside the narrative frame and link Joyce's achievement 
in composing the novel over that decade to Stephen's predicament, implying that the book is one that Stephen might one day be capable of writing, but firmly indicating that it is the mature Joyce and not the immature Stephen who is best placed to formulate emancipatory anti-colonial art.

Het Verdriet plots a similarly convoluted progression towards Louis's discovery of his artistic potential, the style maturing apace with Louis's development. Claus's working notes for Het Verdriet reveal his intention that 'The parts written by Louis multiply towards the end of the book.' [Het geschrevene, door Louis, vermeerdert zich naar het einde toe.] Part I, 'The Sorrow' concentrates on Louis's school days. It is focalised through Louis's young mind, but with the odd naive lapse where Louis's thoughts are momentarily relayed in the first person. Part II, 'Of Belgium', remains primarily focused on Louis's experiences but presents the realities of Flemish life during and after the Second World War in greater detail. Part I concludes with the self-conscious sign-off 'THE END November 1947', the significance of which is brought into sharp focus in Part II, where it is revealed that the preceding section is in fact a novella written by Louis and entered into a competition for 'a short story with a personal flavour, connected directly or indirectly with the war' (501) [een novelle met persoonlijke inslag die rechtstreeks of onrechtstreeks met de oorlog te maken had (649)], announced by the daily Het Laatste Nieuws. This gesture plays across the narratorial ambiguities of the semiautobiographical Künstlerroman in a comparable way to Portrait, implying that the whole text is just the kind of book that an author with Louis's experience and precocious talent might eventually write. The glitches in Part I, where young Louis forgets to maintain his artistic distance and 'accidentally' writes in the first person, or gives himself away by referring to characters not by their names but by reference to their relationship to him, function both as a token of his comparative artistic immaturity and a trail of breadcrumbs that encourage the attentive reader to perceive the true form of the book before it is formally revealed.

Indeed Claus's preparatory notes for the novel suggest that interpretation can be pushed further still: 'What if it would become clear in the last part that the entire book were written by Louis, who uses the I form (which appeared all too frequently earlier, but as a stylistic device) without holding back. E.g., in diary form the story of Holst + girl after the novel form'. [Als nu eens het hele boek in 't laatste deel zou blijken geschreven te zijn door Louis, die dan de ik-vorm (die al te vaak opdook 
eerder, maar dan als stilistisch middel) zou hanteren zonder enige retenue. Bvb. In dagboekvorm het verhaal van Holst + meisje ná de romanvorm.] Unlike Joyce, who gives the narrative over to Stephen at the end of Portrait to signal a new, albeit unfinished, stage in the development of his artistic personality, Claus embeds a fragment of Louis's diary roughly a third of the way through Part II, 'The Sorrow'. The entries record select events on days six to twenty-six of Louis's stay in Mecklenburg through the Kinderlandverschickung, a holiday programme for members of the National-Socialist Youth of Flanders (NSJV) where they learn 'games and folk dancing [...], handicrafts and amateur dramatics, nature study and drill' (381-2) [sport en volksdans, knutselen en lekespel, natuurleven en troepdienst (483)]. Amid telegraphic records of trivial events, three entries perform a similar function to Stephen's avowal of artistic intent by constellating the embryonic qualities that would equip Louis to become the posited evasive, unreliable and highly manipulative author of Het Verdriet. On the nineteenth day, Louis introduces a sequence of events that lead to him being mistaken for an Allied parachutist and captured by German peasants carrying scythes, with the reflection 'What a Geschichte. I am writing it down now because I will laugh about it later' (384; translation amended). [Wat een Geschichte. Ik schrijf het op omdat ik er later om zal lachen (486).] On the twentysecond day, he notes the admiration his political caricatures attract. And on the twenty-third day, he evades trouble with the lie that his father is a member of the Gestapo. These vignettes reveal Louis's gift for narrative, satire and deception.

In Part II of Het Verdriet Claus's play with narrative form both resembles and at times exceeds Joyce's experiments in Portrait, moving in the direction of the admittedly more structured perpetual stylistic innovation that characterises the later chapters of Ulysses, by continually mixing different narrative modes. Some of the experiments are clearly Joyce-inflected, for instance a love letter from Bekka Cosijns, a woman every bit as earthy and sexual as Joyce's Molly Bloom. Her unlettered prose breaches the formal rules of composition to keep pace with the gushing stream of her thoughts after the groundbreaking style of 'Penelope', the celebrated final episode of Ulysses:

Dearest darling Louis, you probably often have wondered Where has my Bekka got to recently but Darling I couldnt [sic] write earlier since I've been with my aunt Alicia in Baudroux-sur-Mere because something gastly [sic] has 
happened that is my Daddy the fool has been STUPID in Deutschland and made trouble there with his Deutsche Chefs and was thrown into a Deutsche JAIL without apeal [sic] or mercy and nobody knows where and maybe for years because he had a KNIFE on him but he always carries a knife because its handy to have one you know Louis, I must stop myself from crying, wait, dearest little Louis of my heart, I know that you carry me in your heart but you dont [sic] talk about it me neither thats [sic] why I am writing for maybe we'll never see each other again in this life because my aunt Alicia says I must stay here all the war time but I want to get away maybe to Deutschland to seek my Father for no one know [sic] where exactly he is kept in chains [...]. (351) Liefste lieveling Louis, gij hebt waarscheinlijk al dikwijls gedacht Waar is mijn Bekka den laatsten tijd maar Lieveling ik kon niet eerder scrijven van scedert ik bij mijn tante Alicia in Baudroux-sur-Mere ben want er is verscrikkelijk gebeurd dat mijn Papatje die sukkelaar DOM is geweest en daar ruzie heeft gemaakt met zijn Deutsche Chefs en in een Deutsche BAK is gevlogen zonder pardon of medelijden en niemand weet waar en misscien voor jaren omdat hij een MES bij hem had maar hij heeft altijd een mes bij hem omdat dat gemakkelijk bij de hand is dat weet gij toch Louis, ik moet stoppen van het weenen, wacht, nu liefste Louistje van mijn hart, ik weet dat gij mij in uw hart draagt maar dat gij daar niet over spreekt en ik ook niet vandaar dat ik scrijf want misscien zien wij elkander nooit meer in dit leven want mijn tante Alicia zegt dat ik hier moet blijven den tijd van de oorlog maar ik wil hier weg misscien naar Deutschland om mijn Vaader te zoeken want niemand weet waarhij presies in de ketens ligt. (444)

Het Verdriet becomes increasingly fragmentary and elliptical as the novel progresses. The latter half of Part II is marked by abrupt shifts in scene, context, subject and technique, as snippets of third-person narrative that supply details of international, local and personal events (from Louis's perspective) are interspersed with snatches of conversation, sometimes reported but increasingly unmediated, as well as with excerpts from Louis's diary and correspondence. The increasingly fragmentary and elliptical nature of Part II is not necessarily Joycean (though Joyce, of course, played a leading role in innovating that distinctively modernist aesthetic), but the movement from third-person narration towards first-person artistic autonomy maps neatly onto the trajectory enacted in A Portrait. After Louis submits the manuscript of his novella to the offices of Het Laatste Nieuws, the act that marks his effective birth as an artist, the preceding narrative hotchpotch finally gives way to fragmentary first-person reportage as Louis navigates the literary world of the salon 
and fails to hold his tongue. The final words 'We'll see. We'll see. Anyhow.' (603) [We gaan zien. Wij gaan zien. Toch. (774)] strike a similar note of ambiguity to the close of $A$ Portrait, leaving an impression that both fledging artists, having acquired the artistic autonomy bequeathed by the first-person narrative, are nonetheless left standing on a precipice, their futures uncertain.

Joyce uses the Dedalian motif of flight and fall to structure the twists and turns of Stephen's progress in Portrait. Stephen's first rebellious act is triggered by his sense of unfair treatment at the hands of Father Dolan, a schoolmaster who unfairly beats him with a pandybat for not having glasses with him in class, when in fact they were broken by a fellow pupil. The incident reveals the covert homosocial desire and discomfort Stephen experiences in an all-male environment, as he is shown unconsciously associating the punishment he receives with the flogging meted out to pupils who have been caught 'smugging' (35). As Joseph Valente points out, the 'queer quiet pleasure' (38) that Stephen takes in imagining Mr Gleeson's 'white fattish hands' (38) when he canes Corrigan leads him to expect something of the same erotic gratification in the hands of Father Dolan, rather than scalding, tingling pain. Stephen frequently considers himself to be a scapegoat, associating his own sufferings not only with the boys caught 'smugging', but also with those of the fallen nationalist hero, the politician Charles Stewart Parnell and St Stephen, the protomartyr. He is moved to complain to the Rector, which is considered a great triumph among his peers, but is later shown to have caused his father great amusement when he recounts what he heard of the episode during the Dedalus family's Christmas dinner.

As Stephen matures, he begins to distance himself consciously from his peers. On artistic matters he is principled even to the extent that he would rather withstand a beating from his friends than climb down from his assertion that Byron is the greatest poet, even though he is 'a heretic and immoral too' (68). Stephen does not bear malice towards the boys who persecute him and, as Vicki Mahaffey notes, determines to increase his distance from them and the value systems they have unquestioningly absorbed by 'objectifying his sense of his difference through sin'. He acts on this desire with a young woman working in Dublin's squalid brothel district. Following a prayer-retreat and an extended sermon outlining the torments awaiting sinners, fear compels Stephen to enter a renewed phase of piety, driving 'his soul daily through an increasing circle of works of supererogation' (124) that become 
comically austere, including mortifying his sense of smell by sniffing stale urine. His newfound devotion prompts the director of studies to ask him in all seriousness if he has a vocation for the priesthood. Stephen ultimately responds by renewing his resolve to encounter the sins and worldly snares that will nourish his artistic soul.

Stephen's artistic vocation is formulated in relation to his waining faith, his discovery of the mythic promise of his surname and the wayward workings of sexual desire. He consciously recoils from the sight of his school friends frolicking naked in the river. And yet it is against the backdrop of their horseplay, as they dive through the air into the water, that Stephen comes to understand his strange surname, Dedalus, the creator of the labyrinth, as 'a prophesy of the end he had been born to serve and had been following through the mists of childhood and boyhood, a symbol of the artist forging anew in his workshop' (142). His erotic joy is intercut with the boys' cries:

An ecstasy of flight made radiant his eyes and wild his breath and tremulous and wild and radiant his windswept limbs.

-One! Two!... Look out!

—O, Cripes, I'm drownded! (142)

Their naked bodies flying are as much as spur for his artistic vocation as his ecstatic vision of a bird-like girl standing midstream, with her skirt hitched up around her hips, whose 'eyes had called him and his soul had leaped at the call. To live, to err, to fall, to triumph, to recreate life out of life' (145). As Hugh Kenner notes, the motif of flight and fall exemplified by the fate of Dedalus's son Icarus shapes the narrative, whereby each part of the novel 'closes with a synthesis of triumph' that the next part shows to be short-lived as Stephen's horizons broaden. This rhythm structures $A$ Portrait and sets up the expectation that Stephen will err, fall and rise again beyond the conclusion of the narrative. If Stephen is to 'recreate life out of life' (172) successfully, he will need to abandon his fear of kinetic art, delve into the abject aspects of human existence and the sexual impulses that define human behaviour, and embrace the sensual 'wayward rhythms' (150) of words themselves which, as he discovers from his own juvenile poetry, will not stay still, but invite the restless play of signifiers that defines Joyce's most extreme experimental writing. 
Claus likewise looks to other literary texts to provide the mythic shaping patterns by which to chart Louis's development. The most clearly signalled of these is Baudelaire's dictum that 'there are only three honourable vocations, those of priest, soldier, and poet' (311) [Dat er maar drie eerbare beroepen zijn, dat van de priester, van de soldaat en van de dichter (392)]. As Louis matures, he evolves through all three professions. In Part I, under the influence of the nuns at his convent school, Louis imagines he will become a missionary priest in Africa. As is the case with Stephen, the priesthood is a vocation to which Louis is singularly unsuited. Louis's rare moments of piety are likewise provoked by guilt, for instance his bathetic actions on hearing that the calving cow he refused to assist had died: 'For three days Louis wore a black wool mourning thread around his wrist, and all week he prayed to St Francis for forgiveness' (60). [Drie dagen lang droeg Louis een zwart wollen rouwdraadje rond zijn pols, de hele week bad hij Sint Franciscus om vergiffenis (39).]

The delusion that Louis might have a religious vocation is undercut by the counter-Catholic credo he invents as the self-appointed leader of the Apostles, a secret society formed by four rebellious school boys at their boarding school. Louis asserts his creative powers by formulating the Apostles' doctrines, perversely adapting the language and rituals of Catholicism to sanctify the group's activities. An initiation ceremony for a fifth member, Goossens, involves foot-kissing, bottom pinching and a parody baptism, in which Byttebier, one of the Apostles, intones "With cross and salt and water sore, I hereby swear to sin no more"' before urinating copiously over the young initiate's hair (38) ['Met kruis en zout en brandend water hebt ge u nu berouwd voor vroeg of later' (50)]. According to Louis's own personal demonology, 'Mizzlers' ('Miezers'), spiteful phantasmagoric imps whose provenance is uncertain but likely excremental, perhaps 'the invisible droppings angels scatter when they have diarrhea' [de onzichtbare keutels die de engelen verspreiden als ze diarree hebben] or 'God's beads of sweat' (52) [de zweetdruppels van God (68)] are agents visible only to the Apostles and 'always laugh, no matter what happens, even at the worst thing you can imagine. Inaudible, invisible, yet you know that they are laughing' (52). [Miezers lachen altijd, wat er ook gebeurt, ook bij het ergste dat je kan bedenken. Onhoorbaar, onzichtbaar, toch weet je dat ze lachen (68).] Ever the fantasist, the young Louis convinces himself that Holst, a family friend, is in fact an archangel who receives 'orders from the heavenly powers to protect Louis from evil though thick and thin' (170) [die de opdracht gekregen heeft van de hemelse 
krachten om Louis door dik en dun in weer en wind te beschermen van het kwaad (212)]. His belief that Holst 'swept Mama's child to death with a wave of his diabolically flapping wings lest I grow attached to this little brother' [die Mama's kind met de duivelse sidderende wiekende vlerken de dood heeft ingewaaid opdat ik mij niet zou hechten aan dit broertje], so that 'instead I might entirely give myself to the love of Our Lord, which is my calling' (170) [zodat ik nu helemaal kan opgaan in de liefde van Onze Heer, wat mijn roeping is (212)] registers the 'slimy inner civil war' (224) [slijmerige innerlijke burgeroorlog (282)] raging in Louis's narcissistic, adolescent soul as he wrestles with his competing desires for Christian piety, egoism and the strong creative need to invent his own pagan mythology. While there is difference in the detail, nested within a structure descended from Baudelaire is a pattern of prideful piety and deluded dreams of priesthood, ultimately yielding to apostasy and egocentric myth-making, that is familiar to readers of Portrait.

There are many points of divergence as well as convergence. While Stephen and Louis are both formatively influenced by improper art, Louis finds friends who share his fascination with immoral texts. The Apostles react to the Nuns' elaborate Book of Rules by furtively collecting Forbidden Books - a socialist weekly, the libretto of a Broadway musical, a photograph of an actress in her underwear and a biography of George Bernard Shaw - some of which they fervently hope would be included on the Vatican Index of prohibited publications. Whereas Stephen allows himself to be persecuted in order to reify his position as an outsider whose self-willed distance from his friends, family and society will enable him to transcend oppressive structures and produce emancipatory art, Louis is the antagonist, persecuting others to gratify his need to assert himself.

The homoerotic aspects of Louis's behaviour at this early stage in his development suggest that the revelation of his artistic destiny will likewise require that, like Stephen, he transcends the teachings of his Catholic background and comes to terms with the wayward workings of sexuality. Louis's relationship with Vlieghe, another Apostle, is fraught with homoerotic panic. After Vlieghe's thumb is torn on barbed wire, Louis tenderly 'picked up the weightless hand, lifted it to his face, examined the pink fingertip and the curved top of the fingernail [...] and licked it, sucked it' (131) [nam hij de lichte hand op, bracht haar naar zijn gezicht, keek naar de roze vingertop die met de beginwelving van de nagel boven de rafeltjes uitstak en likte eraan, zoog eraan (163)]. Vlieghe tells him to stop, but tellingly does not remove 
his finger. A little later, Vlieghe reactively insults Louis to protect his own sexuality, calling him a 'stinker' [Seynaeve, ge stinkt (164)], publicly insisting 'l'd rather you kept your hands off me' [ik heb liever dat ge van mijn vel blijft (164)] and then running away, leaving Louis to reflect: 'Vlieghe is my mortal sin' (132) [Vlieghe is mijn doodzonde (165)]. As Vlieghe increasingly takes issue with Louis's outrageous fabrications, the distance between them grows to the extent that Louis coordinates a dark retribution for various imagined personal and political crimes that he nonetheless construes as a betrayal of the Apostles, including plotting the downfall of Belgium, working for both the German and the Russian secret service, having a father who is the secretary of the Flemish National League, and being 'an agent of Satan' who 'wants nothing to do with love' (222) [Hij is een agent van Satan die geen liefde wil kennen (275)]. In the final chapter of Part I, Louis punishes Vlieghe for his betrayal by ramming the cast of a knucklebone that the Apostles stole from the sidetable of an elderly, bed-ridden nun between Vlieghe's buttocks until it disappears from view (230). When Louis is collected by his mother the next day, his education interrupted by the outbreak of war, Vlieghe says simply 'You've hurt me, Louis' (231) [Gij hebt mij zeer gedaan, Louis (287)], and as a gesture of forgiveness gifts him a penholder with a picture of the Sacré Coeur basilica in Paris, an icon of Catholicism as well as a symbol of his own martyred love. At the end of the novel, Vlieghe's father brings news that his son died after castrating himself in a desperate attempt to cure syphillis, handing Louis a sealed letter written in Vlieghe's last moments, where he confesses 'Have you ever had any idea how much I loved you?' (562; translation amended) [Hebt gij er een gedacht van hoezeer ik u bemind heb? (719)] and reveals he is biting down on the knucklebone to cope with the pain. Vlieghe also expresses disenchantment with his once cherished hope 'that the revival of Flanders, even under German heel, would meet my ideal' (562) [dat Vlaanderens heropstanding, ook onder de Duitse matrak, mijn ideaal zou geweest zijn (720)], rendering his undignified death a statement on the demise of the sterile notion that an autonomous Flanders could be achieved without catastrophic harm. In Louis's case, it is the unforeseen and distant tragedy of Vlieghe's unrequited desire that leads him to completely reject the politics of his peers. From a similar starting point to Stephen, the broad trajectory of perverted piety, rejection of priesthood, and the inception of heretic personal mythologies, working in concert with an unruly adolescent sexuality, 
unfolds into scenarios which are highly specific to Louis and to Belgium during and after the occupation.

Themes treated by Joyce in Portrait arise time and again in Het Verdriet, reconstellated by Claus into new distinctive formations. As Geert Buelens has noted, both Ireland and Catholic Flanders 'consider themselves (post)colonial regions', with the result that 'nationalist politics play a dominant role in the world of arts and letters'. While it is not therefore surprising that the theme of language should loom large as a site of historical and political contestation in the works of Claus and Joyce, it is notable that both novelists dramatise the linguistic conditions of their respective countries with deft discussions of dialect words. The celebrated instance in Portrait is when Stephen discusses the word 'tundish' with the university's dean of studies, who mistakes that synonym for 'funnel' for a quaint gaelicism (158), when it is in fact 'English and good blunt old English too' (212), as Stephen later establishes. Although Stephen knows English better than the dean does, he resents the encoded colonial history whereby the language, 'so familiar and foreign, will always be for me an acquired speech', reflecting 'I have not made or accepted its words. [...] My soul frets in the shadow of his language' (159). He refuses however to pay in his own life and person for his ancestors' decision to throw off their language and take another and eschews the gaelicist movement. Instead Stephen determines to flee the institutions that bind him by turning them against themselves, stating 'You talk to me of nationality, religion and language. I shall try to fly by those nets' (171).

Accordingly, language is heavily politicised in Joyce's fiction. For instance, when the Englishman Haines condescendingly tries his Gaelic on an old milkwoman (a symbol of Ireland) in the first chapter of Ulysses, she ironically assumes he is speaking French, before making an unnecessarily humbling apology for not speaking the language herself. In later chapters of Ulysses, Joyce avenges himself on English by demonstrating his mastery while mockingly deforming its structures, preparatory to the creation of the chimerical language in which Anglo-Irish is enriched by multilingual puns in Finnegans Wake.

Like Joyce, Claus muddies the perceived purity of a national language that correlates directly, and uncomplicatedly, with national identity. Het Verdriet is written in Dutch, but with a fine ear for the register and cadence of provincial life. Many of the characters draw a distinction between 'proper Dutch' and dialect, seeing the former as an aspirational standard, expressing particular disdain for the French 
formulations that creep into the conversations of Flemings who live in a nation divided by language. At times, these arguments are also sparked by reflections on single words. When Louis is shown using 'what they called punaises, thumbtacks' in the opening of the novel, the parenthetic comment '“"Do you have to call them punaises," said Louis's Grandpa, "when we have a perfectly good Flemish word for them?" But Louis would never have used it, everybody already laughed enough at the way he spoke)' separates the young boy's linguistic sensibilities from those of his countrymen, while drawing attention to the politics of language [met punaises duimspijkers moet je zeggen, eiste Louis' Peter, maar Louis zei het nooit, hij werd al genoeg uitgelachen om zijn uitspraak]. Louis's grandfather is chief among those characters who correct other people's Dutch when it is contaminated with French, but who themselves unthinkingly use non-standard dialect words. As a right-wing traditionalist 'who'd always sworn "All for Flanders, Flanders for Christ!"', he meets an ironic end, hospitalised for insanity, shouting 'nothing but foul language and smut' in French, the sheer filthiness of his language showing up the lunacy of nationalist notions of purity (513).

In 1960, Claus expressed his disgust for the concept of 'purity' in the strongest terms:

Purity! That word brings bile to my mouth! You lot run after this purity, tiptoe through mud, and once you reach the elevated heights of purity you don't even notice your feet are dirty and you soil everything. I'm a proletarian. I live in mud. I know I'm dirty. Then I wash myself. I become purer.

Zuiverheid! Dat woord brengt me de gal naar de mond! Jullie lopen achter die zuiverheid aan, stappen op jullie tenen door de modder en eens op het hoge niveau van de zuiverheid merk je niet vuile voeten te hebben en besmeur je alles. Ik ben een proleet. Ik leef in de modder. Ik weet dat ik vuil ben. Ik was me daarna. Ik word zuiverder.

In Het Verdriet, Claus dramatises this hypocrisy by exposing the rank basis of rightwing arguments about purity, sparing no detail of his own former dirtiness in the guise of his alter-ego, Louis, who makes the same mistake of briefly becoming a member of the National Socialist Youth Movement of Flanders.

Claus's disgust at the fundamental dishonesty implicit in the notion of 'purity' also manifests in his treatment of the bodily abject and his will to depict 'the dirtiness 
of daily life' [de vuiligheid van het dagelijks leven]. The candid portrayal of Louis's sexual activities, as well as Louis's own highly developed sense of the corporeality of the body, owes a great deal to the European tradition of blunt naturalism in which Joyce also wrote. The attention to bodily emissions, excrement, lice, and abject actions such as the picking of noses and toenails, has much in common with the scatological sensibility of Ulysses, where bodily processes are described in equally vivid detail. Both writers justify the vulgarity of their art in the strongest terms as a fundamental part of human existence. Joyce was adamant that 'If Ulysses is not fit to read, life is not fit to live'. Claus responded to accusations that his writing was pornographic, by emphasising the vitalising quality of art that elicits desire:

They will say that it is porn. But the vulgar stands on the side of the vital, on the side of art. How can you appreciate Velazquez if you don't watch porn? Someone who rejects the vulgar is himself most vulgar. How can you forget that side of things? No, you have to grab it, embrace it, take it with you and - if it all goes well - order it. That is the basis of my art.

Ze zullen zeggen dat het porno is. Maar het vulgaire is aan de kant van het vitale, aan de kant van de kunst. Hoe kun je Velazquez waarderen als je niet naar porno kijkt? lemand die het vulgaire afwijst is zelf het meest vulgair. Hoe kun je die kant vergeten? Nee, je moet het pakken, omarmen, meenemen, en - als alles goed gaat - ordenen. Dat is de basis van mijn kunst.

Here Claus's artistic philosophy accords with Joyce's own: in Portrait he has Stephen espouse a theory of art as either 'kinetic' (exciting 'desire and loathing') or 'static' (where the mind is 'arrested and raised above') and who comes down firmly on the side of vital art that moves its audience by admitting the pornographic and the abject (172).

While Stephen and Louis inherit and later drift away from the politics of their fathers, they are positioned as aloof from political debate from the outset, being more stimulated by the workings of language and narrative than by the ideological issues at hand. As a boy, Stephen is 'terrorstricken' (33) as he witnesses a rancorous argument between his father and a family friend during Christmas dinner over the righteousness of Parnell (who was set to negotiate home rule for Ireland, until devout Catholics took exception to his adultery), yet he nonetheless finds that 'the spoken words thrilled him' (32). When the young Louis accompanies his father Staf to Café 
Groeninghe, he finds the environment intimidating to the extent that he is wary of crossing the hall to the toilets. The café displays pictures of the Congress of the VNV (the Flemish National League) on the walls and is a regular haunt of Flemish nationalists, including Staf, who is a member of fascist organisations and collaborates actively with the German occupiers. The Groeninghers discuss intelligence from Joris van Severen, the leader of Verdinaso, the League of DutchSpeaking National Solidarists, a Flemish fascist movement that desires 'the creation of the ideal State [...], uniting all Dutch-speaking peoples' (101) [Joris van Severen, de leider van de Dinaso's die op zoek was naar het ideale Rijk, dat van alle Nederlandstaligen (127)], which leads Staf to reflect that 'Here, as always, it's a matter of language' (103) ['t Gaat hier, lijk in alles, om een taalkwestie (129)]. Louis is briefly embarrassed after he spontaneously toasts Mijnheer Leevaert using the French word 'Santé', rather than the Flemish word 'Gezondheid' (101). But, tellingly, Louis becomes more concerned with his pressing need to urinate than the political chit-chat, preoccupied with what would happen if he were to wet himself: 'Would anyone notice? Weren't all these Groeninghers too wrapped up in their own tales?' (101). [Of iemand het zou merken. Zijn de Groeninghers niet allemaal opgeslorpt in hun eigen verhalen? (127)] What strikes Louis most about the experience is the ease with which his father lies about his allegiances when Mijnheer Leevaert needles him about his brother's recent signing to the Stade Walle football team, controlled by French-speaking directors. Not only is Staf's integrity impugned, but the implication is that the 'tales' of the Groeninghers are to be taken with a pinch of salt. Like Joyce, Claus dramatises contemporary political debates about sovereign identity, criticising the occupiers and undercutting crass nationalism, while avoiding directly committing himself or his protagonist to the pronouncements of any single group or movement by ultimately privileging aesthetic considerations.

The period when Louis naively joins the National-Socialist Youth of Flanders corresponds to the second profession in Baudelaire's triad, that of the soldier. This new phase in Louis's life is treated in Part II of Het Verdriet, 'Of Belgium', which places Louis's 'slimy inner civil war' in the broader context of the war raging across Europe, from the time that the Germans advance through Belgium to the liberation, and subsequent fallout for the citizens, including reprisals against collaborators and court cases for those like his naively patriotic father, Staf, who is responsible for coopting Louis into becoming involved in the collaboration, and who is ultimately 
arraigned for his involvement with Nazi officers. Again the honourability of Baudelaire's professions is called into question, because Louis's behaviour is abhorrent. When he joins the Nationalist-Socialist Youth of Flanders, he gives the names of teachers at his school who say that its activities are against Catholicism. $\mathrm{He}$ also discovers that his mother is having an affair with a German, a circumstance that reinforces his distance from her. After a short time, Louis is drawn away from the violent activities of his fascist youth group by the strong lure of his sexual desire (now consciously directed at women) and his intellectual curiosity. Far from romanticising his erotic encounters with women as spiritual experiences, as Stephen does, Louis's interactions with female partners are physical. He is distressed both by failing to achieve an erection with Simone and by the coarse language she uses when she reveals she has been unfaithful. He loses his virginity to his Aunt Nora, who forcefully seduces him, her name a possible allusion to Joyce's wife, Nora Barnacle, and perhaps a token of the incestuous closeness of Claus's own literary relations with Joyce's oeuvre. Unlike Stephen, who renounces Catholicism after he discovers the more intensely spiritual experience of sexual desire, Louis sardonically detaches himself from its teachings while observing its rituals, attending Mass 'regularly, almost daily, taking into his mouth the God of Mercy (in Whom you must believe, or you might as well string yourself up)' (334). [Hij ging weer regelmatig naar de mis, ontving bijna dagelijks in zijn mond de God van Erbarmen (waarin je moet geloven anders kan je je meteen aan een balk ophangen) (421).]

Louis discovers his true artistic vocation when he is co-opted by his father into salvaging valuable commodities from a consignment of forbidden books by 'degenerate' and Jewish authors that have been confiscated by the Nazis and are held under armed guard:

If there are any 'others' to whom I belong, want to belong, they are the ones, those fragmented Cubists, Expressionists, all the other ists. (443)

Als er anderen zijn bij wie ik hoor, wil horen, zijn zij het, de versplinterde kubisten, expressionisten, al die tisten. (564)

Prior to this discovery, Louis had only been exposed to a fairly narrow version of the Flemish tradition, with writers such as Philip de Pillecijn, a New Order adherent who actively collaborated with the Nazis during the occupation of Belgium and was imprisoned for it after the war, whose 'High-sounding but simple' (228) [Weids maar 
toch simpel (284)] prose is recommended by a priest who recognised Louis's precious talent, but wanted to curb his instinctive stylistic extravagance. Having had his sense of artistic destiny quickened by the discovery of culture beyond Flanders, Louis rejects the political ideologies of his family and community, and applies himself to developing his writing. This final swerve marks Louis's entrance into the third of Baudelaire's 'honourable' professions - that of poet or, more broadly, artist. But while Claus has used Baudelaire's dictum to provide an overarching shape, the relation is again ironic, since Louis's behaviour remains dishonourable, at least in the eyes of his family. Like Stephen, whose mother prays that travelling abroad will help him to 'learn [...] away from home and friends what the heart is and what the heart feels' (213), Louis endures approbation for this behaviour and his refusal to conform to expectations. His behaviour is less heroic than Stephen's callous, but finally principled, withdrawal from his family and friends. Stealing coins from his Aunt Violet's purse, Louis is told 'The sorrow of Belgium, that is what you are' (410) [Het verdriet van België, dat zijt gij (521)], a throwaway, clichéd comment that seems right in the circumstances, but is deeply ironic in that it will be Louis who (as the ascribed author of Het Verdriet, at least according to its own narrative conceit) will eventually come to see through and transcend the blinkered and small-minded conservatism, religiosity and nationalism that would make many Flemings receptive to the poisonous Nazi ideology, the legacy of which would be a source of deep sorrow for Flanders for years to come.

When Het Verdriet was published in 1983, Belgium in general and Flanders in particular had yet to come to terms with the wartime collaboration and its post-war sanctioning by the state. Many Flemish Catholics especially were in deep denial about the level of collusion with the German occupier or sought to justify it by portraying the collaborators as misguided idealists who were used and betrayed by the Germans, often while fighting against communism, which in their eyes was a greater threat to European civilisation. In the Seynaeves, Claus draws a picture of a 'typical' collaborating family, some of whom are motivated by ideology, others by personal profit or even love, and who imbibe Nazi ideology because of its elective affinities with the conservative Catholic tradition in which they were raised. In this sense, Het Verdriet is a work of historical recovery, in that, as Claus states, it is attempt 'to capture a certain kind of life in south west Flanders, which no longer exists' [ik wil een bepaalde vorm van leven in Zuidwest-Vlaanderen, die niet meer 
bestaat, capteren]. Yet Claus's historical reconstruction does not simply style itself as a corrective, it also refuses the notion of a fixed historical truth, foregrounds the relativity of perspective and alerts the reader to the multifarious ideological fabrications that arise from it. When two critics debate Louis's short story in terms of the historian's responsibility at the end of Het Verdriet, they gesture to the inevitable distortion that arises from a singular perspective where consensus is lacking:

'No, no, and no to your view of history. The ideal history of a people must also include its dreams. No.'

'But, Karel, history is the memory of a people. You have only to distort that memory and...' (601)

'Uw visie op de geschiedenis, nee, nee, nee. De ideale geschiedenis van een volk moet ook zijn dromen inhouden. Nee.'

'Maar Karel, de geschiedenis is het geheugen van een volk. Het is voldoende om dat geheugen te vervormen en...' (771)

The shortcomings of a fixed national history is another of Stephen's preoccupations, particularly in Ulysses, which takes up two years after $A$ Portrait ends, in which he states that 'History [...] is a nightmare from which I am trying to awake'. Joyce's belief that the artist must transcend the claims of history, even as he analyses how the past impinges on the present, resonates with Claus's own position as an artist who maintains an independent position by negating opposing views. Although Claus rejects the idiocy and cultural blinkeredness of the collaborators he describes in Het Verdriet, he does not subscribe to the counter-myth that the answer to Flemish nationalism is Belgian nationalism, refusing to allow readers to see the situation as a simple binary opposition. It is for this reason that Claus, like Joyce, conceives of the aspiring national artist's tortured progress in relation to the figure of the labyrinth, following the twisting path that is Louis's journey towards emancipation from the oppressive ideology of his kin and countrymen.

Evidence for Claus's use of the same ordering myth in the sections of Het Verdriet that correspond most closely to A Portrait comes from one of many extant sets of working notes for the novel, which he conceived as a work in four parts, each with a presiding location, symbols and significations:

I. Haarbeke (labyrinth, 
unconscious,

myth)

Castle against the French.

II. Walrijk (history

opposite of labyrinth

community) - When L. leaves '44. Liberation for him.

III. Bastegem (nature,

primary - open area,

late romantic.

IV. Meulen (village of Verschaeve - Gezelle - Baziel de Craene, literarification

Degeneration.]

I. Haarbeke. (labyrinth

onbewust

mythe)

II. Walrijk (historie

Kasteel tegen de Fransen.

tegengestelde $v$. labyrinth

gemeenschap.) - Als L. eruit weggaat '44. Bevrijding voor hem.

III. Bastegem (natuur

primair - open gebied

laat-romantisch.

IV. Meulen (dorp v. Verschaeve - Gezelle - Baziel de Craene verliteratuuring

Verzieking.)

The trajectory is adapted somewhat in the final text, but the broad outline of the schema remains. At school Louis's unconscious desires are displayed, as well as his boyish enthusiasm for medieval lore and crusading knights, as he is immersed in a culture that posits French-speakers as enemies. With the advent of war, reality intervenes, as Louis is exposed to the momentous events that will become the stuff of history. The 'literarification' (verliteratuuring) that takes place when Louis is exposed to the books forbidden by the Nazis represents the final stage in his ironic transition from priest via soldier to poet.

Beyond the narrative of Louis's evolution, Het Verdriet is itself 'literarified' by his schematic use of literary allusions and myth as well as its proximity to the fragmented, experimental post-romantic literatures and avant-garde artistic movements that informed Claus's own maturation as an artist, and of which Joyce is 
undeniably part. Because Joyce is nowhere explicitly referenced within the pages of Het Verdriet, it is safest to say that the locally specific and distinctive challenges that face Stephen and Louis as they prepare to become artists of the emergent consciousness of their respective nations are universalised by the many ways in which their personal qualities, preoccupations, experiences and attitudes correspond, thereby dignifying Louis's struggles. However, Claus's stated Joycean ambitions, and his use of similar stylistic techniques, formal conceits and structuring myths, reinforces the suspicion that Joyce lurks behind and looms over Claus's work, suggesting an impulse towards Joyce's work which is both comprehensively acquisitive and destructive, whereby fundamentals have been extracted but completely re-purposed. This impulse approaches Bloom's most radical revisionary ratio, going beyond mere 'clinamen' or 'poetic misreading or misprision proper' where the later artist swerves away from his predecessors, towards an overpowering of the precursor and his effective erasure within the work in the relegation of Joyce from one-time advertised model for literary ambition to a diffuse intertext.

Signs that Claus may have come to reconsider the desirability of linking his work to Joyce are present in his critical commentary produced in the later years of the composition of Het Verdriet and after, where he variously omits to mention Joyce when he is the obvious example, snipes at Joyce's less appealing personal habits and resists what he deems to be wrongful comparison. For instance, when Claus reflects at length on the necessity of developing novelistic schemata, he focuses on an author who lacks that discipline:

The schema lies next to me on the table and I change it constantly, because, while writing, you are constantly faced with surprises. That's the only adventurous aspect of writing: you discover something. And the moment I discover something, I have to change my schema. I can't imagine a writer working without a schema. Yes, Julien Green doesn't use a schema and you can see it in his books. There is no coherence.

Het schema ligt naast me op tafel en ik verander het voortdurend, want je komt, al schrijvende, voortdurend voor verrassingen te staan. Dat is het enige avontuurlijke van schrijven: je ontdekt iets. En zodra ik iets ontdekt heb, moet ik mijn schema wijzigen. Ik kan me niet voorstellen dat een schrijver zonder schema werkt. Ja, Julien Green gebruikt geen schema, en dat is aan zijn boeken te zien. Er is geen samenhang. 
The natural example of a skilled schematist would have been Joyce, who succeeded in generating so much interest in the two Odyssean schemata he developed for Ulysses that they are typically printed in editions of the novel as appendices.

By 1978-roughly the time that Claus claimed to have burned parts of the early draft-the tone of Claus's commentary on Joyce shifted from straightforward praise, becoming sharper and more inscrutable. In an interview with the author Jan Brokken that year, Claus asserted that it was laziness that prevented him from emulating Joyce's selfish single-minded pursuit of greatness:

I would like to go through life like a James Joyce. He had an almost cruel and passionate way of making everything subordinate to writing. He exploited his friends shamelessly, let them do his shopping, he cajoled, he betrayed, and all for The Book. Beautiful. I can't do that. I get distracted by frivolous little visits. I am by nature bone idle.

Ik zou als een James Joyce door het leven willen gaan. Hij had een bijna wreedaardige en hartstochtelijke manier om alles ondergeschikt te maken aan het schrijven. Hij buitte vrienden schaamteloos uit, hij liet ze boodschappen doen, hij bietste, hij pleegde verraad, en dat alles om Het Boek. Prachtig. Mij lukt dat niet. Ik laat me afleiden door frivole bezoekjes. Van nature ben ik aartslui.

In another interview that year, Claus indirectly expressed concern that his originality, and therefore the force of his work, might be diminished by a comparison to Joyce, when he testily complained about the tendency of reviewers to forget the paradox that the most original work is often the most derivative:

And then there's all that howling about plagiarism. The ancient Chinese considered it a compliment when you said the work resembled something else. For the Flemish reader, you have to fall out of a tree and immediately write a Ulysses.

En dan dat gehuil over plagiaat. Bij de oude Chinezen was het een kompliment als men zei dat het werk ergens op leek. Bij de Vlaamse lezer moet je uit een boom vallen en direkt een 'Ulysses' schrijven.

The weight of expectation clearly exercised Claus, who had now transferred the burden of Joycean expectation from himself to his readers. 
The most telling piece of evidence in the incomplete puzzle that is Claus's riddling relationship to Joyce is the strength of Claus's intensely annoyed reaction to a single slip-up in the French translation of Het Verdriet, which confirms that the anxiety of influence weighed heavily on his mind:

When the book was finished I asked my mistress at the time: 'What would you like to be the last word of my book?' Whatever she would have said, 'Pegasus' or 'ashtray', I would have written it down. Then she said 'still'. And so that's what it says. But in the French translation, it says 'Ouil' I was astonished. Because ending a book with 'yes' indicates that you approach the future with optimism. And if you are a little bit cultured you know that the greatest book of the last hundred years, Ulysses by James Joyce, ends with 'yes'. Readers don't know that, but I find it sheer torture myself. I'm absolutely mortified.

Toen het boek af was,vroeg ik aan de maîtresse van het ogenblik: 'Wat zou je willen als laatste woord in mijn boek?' Wat ze ook gezegd had: Pegasus, of asbak, ik had het opgeschreven. Toen zei ze: 'Toch.' En zo staat het er dus. Maar in de Franse vertaling staat er: 'Oui? Ik was verbijsterd. Want een boek eindigen met 'Ja', dat betekent dat je de toekomst stralend tegemoet ziet. En als je een beetje cultuur hebt, weet je dat het grootste boek van de laatste honderd jaar, Ulysses van James Joyce, eindigt op 'Yes'. Een lezer weet dat niet, maar zelf vind ik het een foltering. Dan schrómpel ik in elkaar.

On the surface, Claus was clearly riled by the Joycean resonance introduced by the translator, apparently unwittingly, as much as by the change in meaning. However, his relationship to Joyce as an abjured forebear is more complicated than a simple rebuttal. In another interview, the novelist declared that he was very pleased with the word his mistress bequeathed to him, being 'a word that indicates affirmation and yet calls everything into question at the same time', [een woordje dat op een bevestiging duidt en dat toch weer alles in twijfel trekt]. Yet, the act of giving the last word of his novel over to his female lover itself has an inescapably Joycean resonance of which Claus could not have been unaware, especially given his use of unlettered interior monologue in his representation of Bekka's feminine prose.

Fifteen years after the publication of Het Verdriet, the tone of Claus's commentary on Joyce remained backhanded: 
Joyce was a master in his persona, more so than in the products he delivered. I worship him still because he is the model of the writer. The writer who also plays a load of very arrogant tricks in order to annoy people and to flaunt his erudition to excess. Those are all good writer's traits.

Joyce was een meester in zijn persona, meer dan in de producten die hij afleverde. Ik vereer hem nog omdat hij het model is van de schrijver. De schrijver die ook een portie hele arrogante capriolen uithaalt om de mensen lastig te vallen en te protserig te doen met zijn eruditie. Dat zijn allemaal goeie schrijverseigenschappen.

These ad hominem criticisms serve to distance Claus from the substance of Joyce's works, while simultaneously expressing admiration for his artistic persona, of which his works are product, and his writerly wiles. The slippage from Joyce as the model of the writer to a trickster whose techniques also happen to be 'good writer's traits' quietly diminishes his originary genius.

It would seem that Claus's early desire to announce Joyce as a model for his literary ambition was progressively weakened as Het Verdriet acquired a shape that in many respects resembled Joyce's work, however ambivalently. Whereas Claus deemed the first drafts too heavily orientated towards his own personal psyche, finding them lacking in the necessary ironic distance or universal perspective, the work as a whole nonetheless required that his young artist appeared an autonomous and independent self-creation in possession of the singular sensibility that would, in time, enable him to initiate a new understanding of his national history. For this reason, while Joyce loomed large on Claus's literary radar, Claus's own ego required that the strength of the influence be sublimated. To elevate Joyce's works to the status of informing myths, containing universal elements that can be reconstellated and reworked, is also paradoxically a destructive gesture that simultaneously divests him of his uniqueness. By diffusing these Joycean universals throughout Het Verdriet Joyce becomes not the shining exemplar, but instead disappears into the work as an unmarked, if pervasive intertext of Claus's unique creation. Stephen's dictum (cribbed from Gustave Flaubert) that 'The artist, like the God of the creation, remains within or behind or beyond or above his handiwork, invisible, refined out of existence' (181) might well be applied to Joyce: the exemplary creator whose example Claus engulfed. 


\section{Authors:}

Bram Mertens (bram.mertens@nottingham.ac.uk)

German Department, Trent Building, University of Nottingham, University Park, Nottingham NG7 2RD

Sarah Davison (s.davison@nottingham.ac.uk)

School of English, Trent Building, University of Nottingham, University Park, Nottingham NG7 2RD 